\title{
The Georgia Crisis: Implications for the Partnership for Peace
}

\author{
Graeme P. Herd and Daniel A. Flesch *
}

\section{Introduction: The Immediate Context}

On 7 August 2008, Georgia attacked Tskhinvali, the capital city of South Ossetia, with heavy artillery, rocket launchers, and ground troops in an attempt to take control of the breakaway republic, which contained bases of both Russian and OSCE peacekeepers. Russia, claiming to be acting under the mandate of peace enforcement, pushed Georgia out of both South Ossetia and another breakaway Georgian republic, Abkhazia, and deep into Georgian territory. This created the potential for regime change, as the Russian Army appeared to be moving on Tbilisi with the intent of overthrowing Georgia's democratically elected government. On 8 August 2008, Russian military forces crossed the Georgian border into South Ossetia and Abkhazia in a successful effort to repulse Georgian troops. The immediate casus belli for Russia was genocide, with claims that "over two thousand" South Ossetians had been killed by Georgian troops, along with the shooting of ten Russian peacekeepers in South Ossetia, which necessitated a humanitarian and peace enforcement operation. The Russian advance included ground troops, tanks and armored personnel carriers, and air and sea operations, combined with coordinated kinetic and cyber attacks. Russian forces also crossed into Abkhazia in defense of their compatriots - 70 percent of the Abkhaz population of 220,000 are Russian passport holders, and 90 percent of the South Ossetian population of 70,000 are also Russian citizens.

Russia continued its assault beyond the borders of the breakaway republics, advancing well into Georgia, capturing the strategic military base near Senaki, and proceeding as far as the Black Sea port city of Poti, to sink Georgian vessels and complete its naval blockade, destroying or removing military hardware and materiel along the way. The United States, along with the member states of NATO and the EU, understood this advance to constitute an escalation of the conflict and questioned Russia's need to establish a "security zone" beyond the South Ossetian and Abkhazian borders inside Georgia proper. The short-term international response focused on brokering a ceasefire, sending humanitarian aid to Georgia and North Ossetia, increasing the presence of international monitors in the region, and returning the parties to their pre-conflict positions. Longer-term responses focused on analyzing the geo-strategic impact of the crisis on regional stability and on relations between Russia and the West, and consequently on developing an appropriate policy response. Both sides in the conflict attempted to claim legitimacy for their actions. For Georgia, the breakaway republics

Dr. Graeme P. Herd is a resident faculty member at the Geneva Centre for Security Policy (GCSP) - a PfP Training Center-where he is co-director of the $23^{\text {rd }}$ International Training Course and $3^{\text {rd }}$ Masters in Advanced Studies (MAS) in International and European Security. Daniel A. Flesch is a Political Science \& History Major at the University of Illinois at Urbana-Champaign and was an intern at the GCSP from September to December 2008. 
have long presented a national security issue related to its very statehood, as they touch on Georgian sovereignty and territorial integrity. For Russia's part, it feels that a threat to its national security will arise if Georgia becomes a member of NATO, and if the Alliance is enlarged to include other states in the Black Sea littoral. Moscow would view these developments as part of a concerted pattern of Western encirclement - including such steps as the installation of Ballistic Missile Defense systems in Eastern Europe; Kosovo's unilateral declaration of independence; the Conventional Forces in Europe Treaty; the so-called color revolutions in Ukraine and Georgia, which Moscow understands as CIA/Soros Foundation-sponsored, post-modern coups d'etat; and the post-9/11 presence of U.S. bases in Central Asia. Moscow interpreted these steps, along with Western support of Georgian actions against its breakaway republic, as signs of a pattern of encroachment and containment that Russia was determined to halt and roll back.

Russia viewed its intervention as a military, political, and strategic victory. President Medvedev referred to 8/08/08 as "Russia's 9/11": "the United States and the whole of humanity drew many lessons from September 11, 2001. I would like to see August 8, 2008 result in many useful lessons as well." ${ }^{1}$ However, the Georgia crisis created additional points of tension between Russia and the West, rather than resulting in a shared perspective. These tensions centered on the proportional use of force by Russia, Russia's compliance (or lack thereof) with UN Security Council Resolution 1808 (which recognizes Georgia's territorial integrity and sovereignty), and Russia's recognition of South Ossetia and Abkhazia as independent states. In addition, after President Medvedev of Russia and President Saakahvili of Georgia signed a ceasefire (brokered by President Sarkozy of France), growing differences in interpretation of the ceasefire between Russia, the EU, and Georgia increased tensions, as did ambiguities within the ceasefire agreement itself. For example, Russia understood the agreement to provide for a buffer zone within Georgia proper, while the U.S. and EU argued that the ceasefire did not allow for this interpretation.

When one analyzes the motives behind the aggressors' actions, their different geostrategic goals can be seen as further exacerbating these tensions. Russia claims it was acting to protect civilians holding Russian passports in the breakaway republics, but many believe their real strategic objective was to destabilize Georgia and cement Russian control over the energy pipeline running through Georgia, further increasing Europe's dependence on Russian energy resources. Supplies of energy flowing through Georgia to Europe have been cut by an estimated one million barrels per day, and Europe is already (as of November 2008) feeling the impact of the crisis, as three percent of its oil comes through the Baku-Tbilisi-Ceyhan pipeline.

While much of the recent literature on the situation in Georgia has focused on analysis of the South Ossetia crisis and its implications, little attention has been given to viewing the crisis from the perspective of the Partnership for Peace (PfP). What do

1 Janet McBride, “Medvedev Condemns Georgia NATO Membership Promise,” Reuters.com (12 September 2008); at www.reuters.com/article/topNews/idUSLC66333720080912?feed Type=RSS\&feedName=topNews. 
Russia's actions in the South Caucasus imply for NATO's PfP program? This article will address both the short-term and long-term implications of the August 2008 crisis in Georgia for NATO’s PfP program.

\section{Responses: Russia, EU, NATO, and U.S.}

Salome Samadashvili, Georgia's Ambassador to the EU, has argued, "either we find a way to respond to [Russia's military action] together, or we have to live with the decision that we will face a different world tomorrow." ${ }^{2}$ The crisis generated various and mixed responses from the United States, NATO, the EU, the CIS, and Russia. Each of these responses can be understood in two different contexts: first, through thematic lenses; and second, in terms of their implications for the Partnership for Peace. The immediate reactions to the conflict-including the roles of the various actors, their responses and exchanges-generated a number of themes that are relevant for the evolution of PfP and which therefore deserve to be highlighted and analyzed. Such analysis will enable us to better understand the changing geopolitical context and security environment in which the member states of PfP and NATO find themselves.

The mixed nature of the responses to the Georgia crisis is evident both within NATO and the EU and between NATO and Russia. Germany, France, and Italy have all issued differing statements on their response to the crisis. German Chancellor Angela Merkel diplomatically observed, "It is rare that all the blame is on one side. In fact, both sides are probably to blame. That is very important to understand.” Her Italian counterpart, President Silvia Berlusconi, noted that Saakashvili would do well to "behave." French President Nicolas Sarkozy, who held the EU presidency at the time of the crisis, attempted to broker a ceasefire agreement; however, that agreement was riddled with ambiguities (as we have noted) that were then exploited, despite warnings of "serious consequences." 3 The measured tone of these responses from Germany, France, and Italy were less strident than those from the U.K., Sweden, and the EU member states in Central and Eastern Europe that were brought into the Union in 2004. The old divisions between Atlantic Europe, Core Europe, Non-Aligned, and New Europe evident during the build-up to the invasion of Iraq in 2003 had been realigned. The key explanation cited by many analysts for the divergence in responses was based on dependence on Russian hydrocarbons rather than on policy differences, with France, Germany, and Italy all signing bilateral agreements with Gazprom to ensure the security of their national energy supplies.

As for NATO, it froze cooperation with the NATO-Russia Council (NRC) on 21 August 2008. This reaction came on the heels of NATO Secretary-General Jaap de Hoop Scheffer's initial expression of "serious concern" at the outbreak of fighting, and

2 “NATO, EU Hold Emergency Talks on Georgia,” Deutsche Presse-Agentur (11 August 2008).

3 Dominic Hughes, “Sarkozy’s Georgia Gamble Pays Off,” BBC News (13 August 2008); available at http://news.bbc.co.uk/1/hi/world/europe/7559222.stm. 
his call to "all sides to end the armed clashes and return to the negotiating table." When Russia stalled and exploited the ambiguities of the ceasefire agreement, Scheffer increased the urgency and directness of his rhetoric, expressing, on behalf of an emergency NATO ambassadors' meeting, "solidarity with Georgia.” The Secretary-General also condemned and deplored the "excessive disproportionate use of force by the Russians." He concluded by reiterating forcefully the need for the "full respect necessary for [the] sovereignty and territorial integrity of Georgia," including Abkhazia and South Ossetia. ${ }^{5}$ The irony evident was that Russia had withdrawn from the NRC when NATO member states recognized Kosovo as an independent state in February 2008; now NATO froze relations when Russia recognized Abkhazia and South Ossetia as independent in August 2008. The NRC was deemed more useful by both NATO and Russia as a symbolic marker and vehicle for strategic signaling than for its primary and ostensible purpose: a forum for discussing issues of strategic importance between partners.

Dmitry Rogozin, Russia's envoy to NATO, has described NATO's reaction to the conflict as "inappropriate, dishonest, hypocritical and deeply cynical ... a narrow, bloc-based approach as if they were frozen in the Stone Age of the Cold War." Military cooperation between Moscow and Brussels has stalled, including "the freezing of visits to Russia by NATO officials (including Scheffer's planned October visit); suspending participation in joint military exercises, in Operation Active Endeavour, and not allowing NATO ships to dock in Russian ports; and freezing cooperation with PfP.” However, political dialogue remains open with respect to operations in Afghanistan, which requires the overland transport of non-military supplies through Russian territory. Rogozin views Afghanistan as a shared problem, and warns that "it would be madness for NATO to pursue the path of worse relations with Russia," especially considering the International Stabilization and Assistance Force's (ISAF) struggle to put down the Taliban-led insurgency there. ${ }^{6}$

What currently concerns Russia is the increase of naval activity in the Black Sea, particularly the presence of NATO forces in the north-eastern sector. ${ }^{7}$ The Deputy Chief of the General Staff of the Russian Armed Forces, Colonel-General Anatoly Nogovitsyn, expressed bewilderment at the presence of (according to his sources) nine warships from NATO countries in the area. "NATO is continuing to build up the Navy

4 Ibid.; Radio Free Europe/Radio Liberty, "Large-Scale Fighting Erupts in South Ossetia," GlobalSecurity.org (8 August 2008); available at www.globalsecurity.org/military/library/ news/2008/08/mil-080808-rferl01.htm.

5 Jaap de Hoop Scheffer, "Press Point," NATO.int (12 August 2008); available at www.nato.int/docu/speech/2008/s080812e.html.

6 Alexander Osipovich, "Russia Freezes Cooperation with NATO, but not on Afghanistan," Agence France Presse (26 August 2008).

7 For more complete historical and political background involving the Black Sea region, including Ukrainian membership in NATO and Russian security and military concerns, see James Sherr, "Security in the Black Sea Region: Back to Realpolitik?” Southeast European and Black Sea Studies 8:2 (2008): 141-53. 
group in the Black Sea. For what? They are trying to convince us that this is a planned exercise. ... It is hard to believe that their movement is going on within the framework of delivering humanitarian aid." " Nogovitsyn continued to emphasize that the build-up of warships in the Black Sea "is increasing the degree of tension in the region." Surprisingly, Nogovitsyn commented that Russia, despite having the ability, is "not planning to increase our Black Sea naval group." ${ }^{\text {"9 }}$ Instead, in response, Russia strengthened its defense of the new sovereign state of Abkhazia through the deployment of the Moskova missile cruiser to the port of Sukhumi. The maintenance of the political dialogue between Moscow and Brussels — even at a sharply curtailed level—can therefore be understood as a sign that Russia recognizes the military presence, and perhaps superiority, of NATO naval forces in the Black Sea, and is attempting to respond in kind by curtailing its participation in PfP activities and reminding NATO that the road to Kabul increasingly runs through Moscow.

Before the crisis, NATO and the U.S. had been actively working to increase the security and military potential of the PfP member states. On 3 September 2008, NATO reiterated its intent to help develop Georgia's military capabilities as a part of the longstanding projects that were established within Georgia's PfP program. The creation of the NATO-Georgia Commission (NGC) by NATO in the immediate aftermath of the Georgia crisis was viewed with alarm in Moscow. The NGC was established to "underpin Georgia's efforts to take forward its political, economic, and defense-related reforms pertaining to its Euro-Atlantic aspirations for membership in NATO." ${ }^{20}$ From the Russian perspective, this was understood as the first step toward the formal integration of Georgia into NATO, a "red line" Russia has made explicitly clear it will not tolerate NATO crossing. It was also perceived to represent the multi-lateralization of what formally had been a U.S.-Georgia bilateral Train-and-Equip program, with expansion of the partnership to include the larger Alliance community.

However, James Appathurai, a NATO spokesman, was quick to stress that NATO "as an organization will not be supplying weapons or arms to Georgia. What NATO can do, and what NATO is doing, is assisting the Georgians in defining their own defense capabilities." 11 Lt. Col. Robert Hamilton, who had run the U.S. military training program in Georgia, also stated, "At no time did the U.S. attempt to train or equip the Georgian armed forces for a conflict with Russia. ... In fact, the U.S. deliberately avoided training capabilities [that] were seen as too provocative.” This is evident in the quick collapse of Georgian troops: “their training didn’t cover conventional-warfare

8 "Russian General Staff Bewildered by NATO Excess Activity in Black Sea," ITAR-TASS (26 August 2008).

9 "Russia Has no Plans to Boost its Black Sea Naval Group,” RIA Novosti (27 August 2008).

10 Georgian Ministry of Foreign Affairs, "Framework Document on the Establishment of the NATO-Georgia Commission" (Tbilisi, 15 September 2008); available at www.mfa.gov.ge/ index.php?lang_id=ENG\&sec_id=550\&info_id=7990.

11 “NATO to Go Ahead with Plans to Help Georgian Military," Deutsche Presse-Agentur (3 September 2008); James Appathurai, NATO Press Briefing, 3 September 2008; www.nato.int/docu/speech/2008/s080903b.html. 
topics like tanks, artillery and helicopters."12 Since 2002, this program had focused on clearing Chechen rebels with suspected ties to Al Qaeda from the Pankisi Gorge, counterinsurgency training, and peacekeeping duties.

The NGC has taken steps to create a Membership Action Plan (MAP) that will prepare Georgia for membership in the Alliance. ${ }^{13}$ While not providing the same level of protection as is granted to NATO member states, under the MAP members may feel obliged to intervene on behalf of an aspirant state, thus establishing at least a temporal security. Georgia, Ukraine, and Azerbaijan are also eager to hasten their own entry into NATO, but Turkey has been calling for a slow integration, and is pushing Brussels not to rush the process. Poland, Lithuania, Estonia, and Latvia have all vocally advocated for the inclusion of Georgia and Ukraine within NATO. ${ }^{14}$ These two nations' MAPs have largely fallen by the wayside, but renewed political pressure from Washington may create the impetus for different avenues to membership. Defense Secretary Robert Gates has probed the issue of finding alternate paths of membership for Georgia, citing non-MAP paths to membership. At a NATO Foreign Ministers meeting in early December 2008, a compromise was reached, with Georgia and Ukraine essentially being offered compensatory alternatives to the MAP, and NATO stating: "We call upon Russia to refrain from confrontational statements, including assertions of a sphere of influence, and from threats to the security of Allies and Partners." 15

Tensions within NATO and the lack of a definitive and unified policy response have not, however, curtailed ongoing field exercises in the region within the PfP framework. The PfP exercise "Cooperative Longbow/Lancer-2008" was launched in Armenia on 29 September 2008, and included multinational brigades in field exercises, with over 900 servicemen from seventeen countries participating (although Russia, Georgia, Azerbaijan, and Turkey did not take part). Major-General Arshaluys Patina, Deputy Chief of the Headquarters of Armenian Armed Forces, notes that the exercise "won't affect the geopolitical situation in the region, as it had been planned long ago, [and] meets the frames of the UN mandate." Patina also expressed hopes "that the exercise will contribute to exchange of experience, development of cooperation and consolidation of peace in the region."16

12 John Barry, “Russia’s Nervous Neighbors,” Newsweek (15 September 2008): 8.

13 "Baltic Countries Considering Clearing Georgia of Conflict Left-Over Explosives,” Baltic News Service (16 September 2008).

14 For a broader approach towards NATO's future and role in Europe, in particular the debate after the fall of the Soviet Union, see Vaclav Havel, "Five Points on the Issue of NATO," New Presence: The Prague Journal of Central European Affairs 11:3 (Summer 2008): 2427.

15 Final Communiqué, "Meeting of The North Atlantic Council at the Level of Foreign Ministers Held at NATO Headquarters, Brussels, 2-3 December 2008” (3 December 2008), PR/CP(2008)153; available at www.nato.int/docu/pr/2008/p08-153e.html.

16 “NATO Exercise 'Cooperative Longbow/Lancer-2008' launched in Armenia,” Yerevan (29 September 2008). 
Armenian Defense Minister Seiran Oganyan identified peace and stability as imperatives for the Caucasus state. As a member of the CIS Collective Security Treaty Organization, Armenia does not intend to pursue NATO membership. "Entry into NATO is not on the agenda of the republic's foreign policy" has been a policy line heard from both former President Robert Kocharyn and current leader Serzh Sargsyan. According to Oganyan, "We pursue only one goal: enhance as much as possible our common peacekeeping capabilities, improve their implementation mechanisms and upgrade the combat skills of our units.... This goal confirms Armenia's determination to perform its obligations as a full member of the international community in ensuring global security." ${ }^{\text {17 }}$ Armenia is intent on maintaining an independent foreign policy but welcomes cooperation with NATO.

Another state that is not pursuing NATO membership is Finland, which shares a long border with Russia. In a survey taken immediately after the Georgia conflict, 57 percent of the Finnish public opposed joining NATO, while 23 percent were in favor, and 20 percent were undecided. The same poll conducted a year earlier revealed that 16 percent of Finns were undecided about NATO membership. Perhaps most telling is the 70 percent who wanted a referendum should Finland seek membership in the military alliance. ${ }^{18}$ Finland, a member of the European Union, does not want to entangle itself in a military alliance in any way that could be seen as a provocation toward Russia. From Moscow's perspective, it appears that Russia's incursion into Georgia has not created an impetus for non-aligned states to rush westward.

It is clear that Russia considers all military build-up in its near neighborhood as a potential counter to Russian actions. On 20 September 2008, Russian President Medvedev ordered an increase in defense spending (particularly procurement) and the beginning of the process of military reform. He also announced a new project to "build new space and missile defense shields and put [Russia's] armed forces on permanent combat alert."19 These responses are part of a pivotal shift that occurred in Russia on 8/8/08. "Russia's 9/11" has accelerated the creation of a new power structure. The Russian president wants to usher in a new world order, one that is not dominated by the United States. In an interview after the Georgia crisis, Medvedev outlined his foreign policy in five points: Russia "(1) recognizes the primacy of the fundamental principles of international law; (2) The world should be multi-polar. ... We cannot accept a world order in which one country makes all the decisions, even as serious and influential a country as the United States of America; (3) Russia does not want confrontation with any other country [and] has no intention of isolating itself; (4) Russia will protect the lives and dignity of our citizens. ... [This] is an unquestionable priority. ... [It] should be clear to all that we will respond to any aggressive acts committed against us;

17 “Armenia Says NATO Exercise Key Factor of Stability in Region,” ITAR-TASS (29 September 2008).

18 “Finnish Voters Still Oppose NATO Membership,” Deutsche Presse-Agentur (18 September 2008).

19 Otny Halpin, “Moscow Begins New Arms Race with Military Build-up,” The Times (London) (27 September 2008). 
(5) There are regions in which Russia has privileged interests ... with which we share special historical relations and are bound together as friends and good neighbors."20 However, Medvedev contends that he did "not believe the Caucasus crisis had caused a fault line in relations between Russia and the West, which would lead to another period of confrontation., 21

Thus, PfP states in the South Caucasus, as well as Ukraine and Moldova, are caught between two competing power structures and potential military-security alliancesNATO and the Russian Federation - and thus between two strategic orientations. In the aftermath of the Georgian crisis, Russia now seems able to set the rules of the game in the South Caucasus in particular, as well as in post-Soviet Central Asia more generally, having demonstrated that it has the military capability and political will to enforce these rules with instruments of both soft and hard power. Russian Defense Minister Anatoliy Serdyukov underscored such an interpretation when he expressed concern "about the build-up of Georgia's military potential being carried out ... and by the pushing of that country into NATO. These activities can provoke another conflict, a far more serious one than the events that took place this August." ${ }^{, 2}$ At the same time, if the EU can be said to have ever had a strategy regarding the South Caucasus, it is certainly now in tatters. NATO has demonstrated a split response, and the U.S. is understandably focused on a sudden financial crisis and a political transition that typically takes between six and nine months to complete. Given such an inauspicious geo-strategic context, what, then, do these events mean for the future of the PfP program?

\section{Conclusions: Implications for the Partnership for Peace?}

In one reading of the Georgia Crisis, it can be argued that Russia has every right to be skeptical of NATO's intentions. As this interpretation has it, "NATO plays an important role in ensuring European security. But by doing this NATO also is exporting instability outside, in particular, to Russia.”23 John Chapman at the London-based International Institute for Strategic Studies has cautioned NATO against rapid or immediate expansion for similar reasons: "A policy of NATO enlargement now ... would be a strategic error. Normally when military alliances enlarge it is to gain strength

\footnotetext{
20 “Russia Won’t Accept Unipolar World - Medvedev,” Interview given by Dmitri Medvedev to Russian television (31 August 2008); available at www.globalsecurity.org/wmd/library/ news/russia/2008/russia-080831-medvedev01.htm.

21 Excerpts from transcript of meeting of President of the Russian Federation D. A. Medvedev with participants in the International Club Valdai, 17 September 2008; available at www.geneva.mid.ru/press/e_2008_29.html. For expanded views on the future of U.S.Russian relations and Russia's new perception of its international role, see Aleksandr Dugin, "Pax Russica: For a Eurasian Alliance Against America," NPQ: New Perspectives Quarterly 25:4 (Fall 2008): 56-60.

22 “Georgia's Accession to NATO Could Cause Serious Conflict," Zvezda TV (18 November 2008).

23 “Russian Apprehensions Regarding NATO Justified,” ITAR-TASS (13 October 2008).
} 
themselves; it is not to assume new strategic liabilities." ${ }^{24}$ Turning the "expansion policy into a game of Russian roulette” is not something Russia is prepared to tolerate, nor is it an option that should NATO even consider. If Ukraine, Georgia, and Finland are not to become NATO members, will PfP and NATO member states reexamine the utility of the PfP program itself? ${ }^{25}$

Events external to the South Caucasus will have significant bearing on this question - perhaps just as much as the Georgia Crisis and its immediate aftermath. 2009 represents a pivotal moment for the future direction and evolution of NATO. In 2007, NATO rejected a Global Partnership Initiative (GPI) that would have given institutional form to efforts to develop more robust advanced expeditionary warfare capabilities, stabilization and reconstruction capabilities in complex crisis management environments, and programs to rebuild indigenous militaries and security forces as part of an exit strategy in areas of intervention. ${ }^{26}$ Through 2008, the chances that NATO will face a strategic defeat for ISAF in Afghanistan increasingly seem to be more rather than less likely. Afghan presidential elections in September 2009 will be critical to NATO's efforts to shape an exit strategy, and to the ultimate perception of ISAF's success or failure. Failure would decrease NATO's credibility and legitimacy, and diminish the utility of PfP within the region, while boosting other regional organizations as compensatory alternatives. It might also encourage states in the region to shift their strategic orientation towards Moscow, with Beijing and the Shanghai Cooperation Organization as a counterweight. For the South Caucasus—and particularly in Azerbaijan-the pressure to adopt Russian-led, Caspian-oriented energy frameworks would increase, and with it Russia's role in training the militaries, shaping the national security strategies, and reformulating the military doctrines in these regional states.

An alternative and more positive response to failure in Afghanistan may be for NATO to place a renewed emphasis on PfP, essentially turning it into "GPI-lite." This would include expanding PfP to include global members eager to refashion their security sector governance (thus pursuing defense reform and interoperability as ends in themselves rather than as stepping-stones to NATO membership), enhance their relationship with NATO's intelligence network, and gain easier access to expeditionary

24 Robin Millard, "Russia Row Shows NATO Needs Reality Check,” Agence France Presse (18 September 2008).

25 See Emanuel Adler, “The Spread of Security Communities: Communities of Practice, SelfRestraint, and NATO's Post Cold War Transformation,” European Journal of International Relations 14:2 (2008): 195-230; and Zdenek Kriz, "NATO Transformation and the Summit in Bucharest: Towards the Organisation of Collective Defence, Collective Security or Cooperative Security,” Defence and Strategy (Prague) 1 (2008): 17-29. These articles offer a debate presenting a theoretical and empirical approach, respectively, to the concepts behind NATO expansion within Europe and through partnerships. The debate centers on the strategies of cooperative security, collective defense, or collective security as centerpieces of NATO's ambitions.

26 For a discussion of this initiative, see Graeme P. Herd and Daniel Kight, "Future Visions of NATO Partnerships and Cooperation Programs," Connections: The Quarterly Journal 6:3 (Fall 2007): 1-9. 
partnerships if NATO chooses to engage in future conflicts in Asia, Africa, the Pacific, etc.

Thus, Georgia’s PfP activities are critical to the evolution of the program. If Russia has not just a voice but also a veto over Georgia's NATO membership prospects, presumably it can shape and delimit the range and extent to which Georgia engages in PfP activities. If this is the case, then Georgia will become a litmus text for the utility of PfP in the South Caucasus, and thus for the strategic orientation of the states in that region. This could prove to be a tipping point for the strategic orientation of Azerbaijan, moving it from an approach that is balanced between orientations toward Moscow and Euro-Atlantic institutions firmly into the Kremlin-controlled security space. As goes Azerbaijan, so go Turkmenistan and Kazakhstan (as their Caspian energy framework is dependent on Baku's choices), and thus the strategic heart of Central Asia. In the context of potential strategic failure for NATO in Afghanistan, this state of affairs is sobering indeed. 


\section{Bibliography}

Adler, Emanuel. "The Spread of Security Communities: Communities of Practice, SelfRestraint, and NATO's Post Cold War Transformation." European Journal of International Relations 14, no. 2 (2008): 195-230.

Appathurai, James. NATO Press Briefing., 2008.

Armenia Says NATO Exercise Key Factor of Stability in Region. ITAR-TASS, 2008.

Baltic Countries Considering Clearing Georgia of Conflict Left-Over Explosives. Baltic News Service (2008).

Barry, John. "Russia’s Nervous Neighbors." Newsweek (2008): 8.

Dugin, Aleksandr. "Pax Russica: For a Eurasian Alliance Against America." NPQ: New Perspectives Quarterly 25, no. 4 (2008): 56-60.

Finnish Voters Still Oppose NATO Membership. Deutsche Presse-Agentur (2008).

Framework Document on the Establishment of the NATO-Georgia Commission. Tbilisi: Georgian Ministry of Foreign Affairs, 2008.

Georgia's Accession to NATO Could Cause Serious Conflict. Zvezda TV, 2008.

Halpin, Otny. "Moscow Begins New Arms Race with Military Build-up." The Times (London) (2008).

Havel, Vaclav. "Five Points on the Issue of NATO." New Presence: The Prague Journal of Central European Affairs 11, no. 3 (2008): 24-27.

Herd, Graeme P., and Daniel Kight. "Future Visions of NATO Partnerships and Cooperation Programs." Connections: The Quarterly Journal 6, no. 3 (2007): 1-9.

Hughes, Dominic. Sarkozy’s Georgia Gamble Pays Off. BBC News, 2008.

Kriz, Zdenek. "NATO Transformation and the Summit in Bucharest: Towards the Organisation of Collective Defence, Collective Security or Cooperative Security." Defence and Strategy (Prague) 1 (2008): 17-29.

Large-Scale Fighting Erupts in South Ossetia. GlobalSecurity.org, Radio Free Europe/Radio Liberty, 2008.

McBride, Janet. Medvedev Condemns Georgia NATO Membership Promise. Reuters.com, 2008.

Meeting of The North Atlantic Council at the Level of Foreign Ministers Held at NATO Headquarters, Brussels, 2-3 December 2008 In Final Communiqué., 2008.

Millard, Robin. Russia Row Shows NATO Needs Reality Check. Agence France Presse, 2008.

NATO Exercise 'Cooperative Longbow/Lancer-2008' launched in Armenia. Yerevan (2008).

NATO, EU Hold Emergency Talks on Georgia. Deutsche Presse-Agentur (2008). 
Osipovich, Alexander. Russia Freezes Cooperation with NATO, but not on Afghanistan. Agence France Presse, 2008.

Russia Won't Accept Unipolar World - Medvedev In Interview given by Dmitri Medvedev to Russian television., 2008.

Russian Apprehensions Regarding NATO Justified. ITAR-TASS, 2008.

Scheffer, Jaap de Hoop. Press Point. NATO.int, 2008.

Sherr, James. "Security in the Black Sea Region: Back to Realpolitik?" Southeast European and Black Sea Studies 8, no. 2 (2008): 141-53. 